\title{
PRAKTYKI ZWINNE W ZESPOŁACH PROJEKTOWYCH - WYNIKI BADAŃ EMPIRYCZNYCH
}

https://doi.org/10.33141/po.2019.03.08

\section{Alina Kozarkiewicz, Paweł Paterek}

\section{Wprowadzenie}

$\mathbf{P}$ owszechna informatyzacja wielu dziedzin życia sprawiła, że zwiększyła się znacznie liczba inicjowanych projektów związanych $\mathrm{z}$ wytwarzaniem oprogramowania, a ich rezultatem są zaawansowane produkty lub usługi stosowane w prawie każdym obszarze działalności człowieka. Rosnący poziom złożoności produktów i usług IT oraz dynamicznie zmieniające się wymagania i oczekiwania klientów oraz użytkowników produktów tych projektów sprawiły, że tradycyjne metodyki, stosowane dotychczas w tego typu projektach, przestały odpowiadać na potrzebę efektywnego zarządzania. Metodyki zwinne, których podstawę stanowi Manifest Agile (Beck i in., 2001), ogłoszony w 2001 roku, stanowią odpowiedź na problemy związane z organizacją pracy zespołów projektowych wytwarzających oprogramowanie. Głównymi zaletami podejścia zwinnego są m.in. szybsza i bardziej trafna odpowiedź na potrzeby rynku - klientów lub użytkowników, zmniejszenie ryzyka strat w organizacji, zwiększenie efektywności i produktywności zespołów projektowych, jak również zwiększenie satysfakcji zespołów z wykonywanej pracy. Obecnie podejście zwinne przestaje być domeną wytwarzania oprogramowania, a tzw. metodyki hybrydowe zyskują wielu kolejnych zwolenników. Zainteresowanie podejściem zwinnym, co wydaje się oczywiste, nie jest wyłącznie widoczne wśród praktyków, również naukowcy coraz chętniej prowadzą badania nad różnymi aspektami zwinnego zarządzania projektami.

Analiza literatury przedmiotu wskazuje na istnienie luki badawczej dotyczącej kompleksowego i systemowego spojrzenia na ogół dostępnych praktyk zwinnych. Jak pokazują analizy, chociaż dostrzega się wielość praktyk określanych terminem „zwinne”, to brak jest ich systematyzacji. Brakuje także dyskusji nad znaczeniem poszczególnych praktyk, w tym nad ich równorzędnością (lub jej brakiem). Dlatego głównym celem badań przedstawionych w tym artykule jest identyfikacja oraz systematyzacja najważniejszych praktyk zwinnych w zarządzaniu zespołami projektowymi, a także próba określenia ich ważności. Ponadto wybór określonych rozwiązań przez zwinne zespoły projektowe motywuje do badań nad uniwersalnością lub specyfiką zastosowań, uwarunkowaniami determinującymi te wybory czy wreszcie nad czynnikami wpływającymi na skuteczność i efektywność stosowania określonych praktyk zwinnych w organizacjach. W prezentowanych badaniach, które - co należy podkreślić - stanowią jedynie etap kompleksowych badań nad zespołami zwinnymi, analizowano zakres wykorzystania praktyk
Przegląd Organizacji, Nr 3 (950), 2019, ss. 51-58 www.przegladorganizacji.pl OTowarzystwo Naukowe Organizacji i Kierownictwa (TNOiK) zwinnych, rozumiany jako częstotliwość ich stosowania w codziennej pracy zespołów projektowych, oraz najważniejsze czynniki wpływające na dobór tych praktyk. Określenie pozycji (rangi) poszczególnych praktyk zwinnych oraz czynników, które warunkują ich stosowanie, było możliwe dzięki wykorzystaniu sondażowych badań ilościowych opartych na skonstruowanym narzędziu badawczym (ankiecie badawczej), a także badań jakościowych - wywiadów z praktykami-ekspertami w zakresie zwinnego zarządzania projektami.

\section{Zakres i uwarunkowania} wykorzystania praktyk zwinnych - wyniki dotychczasowych badań

$\mathbf{Z}$ winne zarządzanie projektami (agile project management) wykorzystuje szereg charakterystycznych praktyk zarządzania ${ }^{1}$, których źródłem są zasady, wartości oraz sposób myślenia określony w filozofii agile (Highsmith, 2004; Schwaber, 2004). Podstawą jest Manifest Agile (Beck i in., 2001), w którym autorzy przedstawili dwanaście podstawowych zasad podejścia zwinnego stanowiących fundament tworzenia i rozwoju licznych praktyk zwinnych (agile practices) (Highsmith, 2004; Boehm, Turner, 2005). Zasady te obejmują: zadowolenie klienta poprzez częste dostarczanie działającej części produktu, gotowość na zmianę wymagań, częste dostarczanie rozwiązań w regularnych odstępach czasu, ścisłą współpracę zespołów biznesowych i projektowych, motywowanie ludzi poprzez okazywanie im wsparcia i zaufania, komunikację bezpośrednią twarzą w twarz, działający produkt jako miarę postępu prac, stały rozwój i postęp zapewniający równe tempo realizacji, ciągłe skupienie na dążeniu do technicznej doskonałości, prostotę jako klucz działania, samoorganizujące się zespoły oraz regularną analizę poprawy wydajności pracy wraz z odpowiednim dostosowaniem działań (Beck i in., 2001). Praktyki zwinne, inspirowane powyższymi zasadami, są fundamentalne. Poza nimi istnieją całe rodziny praktyk inżynierskich, w szczególności związanych $\mathrm{z}$ inżynierią tworzenia oprogramowania, które również klasyfikowane są do tej grupy (Agile Alliance, 2019).

Analiza literatury przedmiotu wskazuje, że praktyki zwinne stanowiły przedmiot badań naukowych w formie systematycznych przeglądów literatury (Jalali, Wohlin, 2011; Karvonen i in., 2017) oraz badań empirycznych, zarówno ilościowych, jak i jakościowych (Sheffield, Lemétayer, 2013; Conforto i in., 2014; Henriksen, Pedersen, 2017). Autorzy 
dotychczasowych badań identyfikowali i opisywali praktyki zwinne pod kątem wsparcia wdrożenia podejścia zwinnego, wykorzystania w metodyce zwinnej, znaczenia dla sukcesu projektu, a także dostosowania tych praktyk do potrzeb zarządzania portfelem projektów (Stettina, Hörz, 2015).

Przykładowe praktyki zwinne zidentyfikowane w literaturze obejmują: codzienne monitorowanie planu i aktualizacje aktywności przez samoorganizujący się zespół, planowanie i realizację zadań w regularnych odstępach czasu zwanych iteracjami, szybkie i częste wydania gotowego produktu do klienta, ciągłe dostarczanie i wdrażanie części gotowego produktu, ciąłą integrację - dającą widoczny efekt końcowej wizji produktu, używanie prostych narzędzi i procesów, częstą aktualizację procesów (np. za pomocą retrospektyw), bezpośrednią i częstą komunikację z interesariuszami projektu (szczególnie z klientem) oraz częstą informację w postaci sprzężenia zwrotnego - w ramach regularnej prezentacji efektów po zakończonej iteracji (Highsmith, 2004; Jalali, Wohlin, 2011; Conforto i in., 2014).

Praktyki zwinne obejmują również część praktyk oraz działań znanych $\mathrm{z}$ tradycyjnego podejścia do zarządzania projektami (Trocki, 2013; Cabała, 2016), podejmowanych głównie w obszarze uczenia się i zarządzania wiedzą (Spałek, 2013; Wyrozębski, 2014; Panasiewicz, Paterek, 2017). Dotyczy to szczególnie projektów informatycznych związanych z wytwarzaniem oprogramowania, wymagających ciągłego i dynamicznego aktualizowania znacznych zasobów wiedzy projektowej (Spałek, 2013; Wyrozębski, 2014) ukrytej w umysłach i doświadczeniu członków zespołów projektowych (Boehm, Turner, 2005). Praktykami zarządzania wiedzą wspierającymi procesy wdrożenia podejścia zwinnego są m.in.: codzienna współpraca i częsta komunikacja w zespole projektowym, udział całego zespołu w planowaniu i realizacji projektu, ciągłe usprawnianie procesu, eksperymentowanie i uczenie się na błędach, regularne aktywności związane ze szkoleniami i uczeniem się, ciągła integracja i weryfikacja, samoorganizacja zespołu oraz dzielenie się wiedzą $\mathrm{w}$ ramach realizacji zadań $\mathrm{w}$ multidyscyplinarnym zespole projektowym (Jalali, Wohlin, 2011; Singh i in., 2014).

Jak wynika $\mathrm{z}$ dotychczasowych badań, sposób doboru i aplikacji stosowanych praktyk zależy od środowiska, kontekstu oraz uwarunkowań (enablers), w których działa dane przedsiębiorstwo projektowe lub zespół projektowy (Wirkus, Zejer, 2017), a w niektórych aspektach również uwarunkowań prawnych decyzji podejmowanych przez kierownictwo (Bojar i in., 2018). Uwarunkowania te mogą mieć charakter wewnętrzny lub zewnętrzny, a także wpływać bezpośrednio lub pośrednio na możliwość lub sposób implementacji praktyk podejścia zwinnego (Vázquez-Bustelo i in., 2007; Conforto i in., 2014; Kozarkiewicz, Paterek, 2016). Najczęściej analizowane uwarunkowania dotyczą różnych obszarów organizacji - struktury, kultury, strategii organizacji, wsparcia kierownictwa, procesów, zespołu projektowego oraz specyfiki samego projektu (Nerur i in., 2005; Vázquez-Bustelo i in., 2007; Conforto i in., 2014). Zakres wykorzystania praktyk zwinnych może zmieniać się w zależności od zastosowanego modelu cyklu zarządzania projektem, a więc może być mniejszy w przypadku znanego rozwiązania w modelu iteracyjnym, a większy w przypadku niejasnych rozwiązań w modelu adaptacyjnym (Wysocki, 2014).

Przegląd literatury pozwala także zidentyfikować kierunki przyszłych badań. Interesujące, nowe zagadnienia badawcze mogą dotyczyć znacznie szerszego zbioru praktyk zwinnych, zależności pomiędzy różnymi praktykami, zależności pomiędzy praktykami a czynnikami projektowymi lub uwarunkowaniami oraz zależności pomiędzy adaptacją praktyk zwinnych a charakterystykami zespołu projektowego (Conforto i in., 2014; Recker i in., 2017).

Należy zauważyć, że chociaż w dotychczasowych badaniach empirycznych autorzy badali różne praktyki zwinne na różnych poziomach zastosowań (np. poziom przedsiębiorstwa, projektu, zespołu), a także stosowali podstawowe klasyfikacje ich rodzajów (np. inżynierskie, procesowe), to brak jest badań w zakresie klasyfikacji (typologii) praktyk zwinnych, ich uniwersalności lub kongruencji. Znaczenie zwinnego zarządzania projektami i wskazane luki badawcze potwierdzają potrzebę prowadzenia takich badań.

\section{Metoda i przebieg badań własnych}

$\mathbf{P}$ rezentowane $\mathrm{w}$ artykule badania stanowią element kompleksowych badań na temat zwinnego zarządzania zespołami projektowymi i wynikających z tego podejścia korzyści oraz ograniczeń. Prezentowany tu etap dotyczy badań przeprowadzonych wśród trenerów metodyk zwinnych oraz ekspertów o znacznym doświadczeniu w praktyce zarządzania. Zasadniczym celem badań było dopracowanie narzędzia badawczego w postaci kwestionariusza ankiety. Spotkania $\mathrm{z}$ trenerami metodyk zwinnych potraktowano również jako bardzo ważną okazję do wywiadów na temat zastosowań, znaczenia, korzyści i ograniczeń wynikających ze stosowania określonych praktyk lub grup praktyk zwinnych. Dlatego też w przypadku tych badań bardzo trudno jest odróżnić etap badań ilościowych i jakościowych. Wywiad z trenerami miał charakter równorzędny i towarzyszył wypełnianiu ankiety badawczej.

W prezentowanych badaniach początkowo wzięło udział 16 respondentów - trenerów metodyk zwinnych, którzy - jak wspomniano - wypełnili również ankietę $\mathrm{w}$ ramach badania ilościowego. W wyniku dalszych starań udało się pozyskać kolejnych 15 ekspertów, doświadczonych praktyków, którzy $\mathrm{z}$ różnych przyczyn nie mogli wziąć udziału w przeprowadzonych wywiadach. Dlatego też próba w pilotażowym badaniu ilościowym obejmowała łącznie 31 ankiet. Niewielka liczność próby spełniała jednak założenia badawcze, próba w tym badaniu była celowa, charakterystyczna dla badań pilotażowych (Nowak, 2012). Należy wspomnieć, że trenerzy i eksperci biorący udział w badaniach zostali wyszukani poprzez portal dla profesjonalistów LinkedIn² oraz za pomocą wzajemnego polecania (snowball sampling). Zasadniczą wadą zastosowanej metody doboru respondentów jest mała reprezentatywność, co ogranicza możliwość uogólniania uzyskanych wyników na inne niż badane tu przedsiębiorstwa.

Przedsiębiorstwa wytwarzające oprogramowanie, które stanowiły przedmiot prezentowanych badań, dostarczają klientom bardzo zaawansowane i złożone produkty lub usługi biznesowe będące najczęściej wynikiem współpracy wielu 
zespołów projektowych ${ }^{3}$ wykorzystujących różne praktyki zwinne. Jak pokazywały wyniki dotychczasowych badań, stosowanie praktyk zwinnych może zależeć w dużej mierze od uwarunkowań, w jakich zespół pracuje. Częścią badania było zatem sprawdzenie zależności wykorzystania praktyk zwinnych od specyfiki zespołu, na przykład od jego doświadczenia w stosowaniu określonej metodyki zwinnej czy od kontekstu środowiska jego pracy. Wskazówki te zostały uwzględnione w pytaniach zadawanych w trakcie wywiadów oraz w ankiecie pilotażowej poprzez odpowiednią konstrukcję metryczki kwestionariusza ankiety.

\section{Charakterystyka próby badawczej}

$\mathbf{P}$ róba respondentów w prezentowanych badaniach ilościowych liczyła 31 specjalistów z zakresu metodyk zwinnych. W badanej próbie proporcje mężczyzn i kobiet były równe ${ }^{4}$. Uzasadnieniem dla określania respondentów terminem eksperci mogą być ich kompetencje - ponad połowa badanych pełniła rolę Agile Coachów. O trafnym doborze badanych może świadczyć także fakt, że 25 badanych z 31 były to osoby $\mathrm{z}$ ponad 5-letnim doświadczeniem $\mathrm{w}$ pracy $\mathrm{z}$ metodykami zwinnymi. Dodatkowo, 22 z 31 badanych w swojej dotychczasowej karierze pracowało $\mathrm{z}$ więcej niż pięcioma zespołami. Kompetencje respondentów może potwierdzić także informacja o odbytych szkoleniach - ponad połowa badanych respondentów odbyła powyżej 10 szkoleń z zakresu metodyk zwinnych.

Wiodącym sektorem, w którym pracowali respondenci, realizując projekty, i do którego odnosili się w trakcie badań (23 na 31 respondentów), był sektor IT związany bezpośrednio z tworzeniem oprogramowania. Pokazuje to trafność doboru respondentów do próby i zgodność $\mathrm{z}$ celem prowadzonych badań (rys. 1).

Jeśli chodzi o charakterystyki zespołów, które stanowiły przedmiot analiz $\mathrm{w}$ badaniach ilościowych, to ponad połowa (20 z 31) badanych zespołów projektowych liczyła 3-9 osób. Zakres współpracy określany przez średnią liczbę innych zespołów współpracujących z badanym zespołem projektowym wynosił 3-9 zespołów (w 26 z 31 badanych przypadków).
Wskazuje to na bardziej złożone projekty, w których uczestniczyli badani. Bardzo interesującym i ważnym elementem, z perspektywy prowadzonych badań, był rodzaj dostępu do klienta (rys. 2) - okazało się, że najczęściej był to dostęp pośredni, np. poprzez specjalny zespół reprezentujący klienta (13 z 31 przypadków), co jest charakterystyczne w dużych przedsiębiorstwach typu korporacja lub software house. Drugim w kolejności był dostęp bezpośredni ograniczony czasowo (9 z 31 przypadków), gdzie najprawdopodobniej przedsiębiorstwu udało się zaangażować klienta na potrzeby współpracy z zespołem, jednak odbywało się to w mniej lub bardziej ograniczonym zakresie czasu.

\section{Zakres i uwarunkowania wykorzystania praktyk zwinnych - wyniki badań ilościowych}

$\mathbf{N}$ a podstawie przeglądu literatury (Jalali, Wohlin, 2011; Karvonen i in., 2017) oraz dotychczasowych wyników badań (Conforto i in., 2014; Recker i in., 2017) utworzono siedem grup praktyk zwinnych obejmujących po cztery praktyki reprezentujące każdą grupę praktyk. Grupy praktyk - zdaniem autorów - reprezentują w logiczny i spójny sposób najważniejsze elementy podejścia zwinnego. Na przykład, grupa zawierająca praktyki dotyczące przyrostowości, iteracyjności i stałego tempa prac jest podstawą do tego, aby zespół mógł dostarczać regularnie fragment działającego produktu. W celu eliminacji złożoności badania wybrano po cztery najważniejsze praktyki w danej grupie. Wybrane praktyki stały się następnie podstawą do skonstruowania narzędzia badawczego (ankiety) do oceny zakresu wykorzystania praktyk zwinnych przez zespoły projektowe. Wybrane praktyki w układzie zidentyfikowanych grup przedstawiono $\mathrm{w}$ tab. 1.

W konstrukcji ankiety badawczej wykorzystano 5-stopniową skalę Likerta, a podstawą pomiaru zakresu stosowania danej praktyki zwinnej była ocena częstotliwości stosowania danej praktyki przez zespół projektowy w stałym, krótkim i regularnie powtarzanym okresie czasu, czyli w pojedynczej iteracji. Ocena dotyczyła każdej z 28 praktyk, następnie

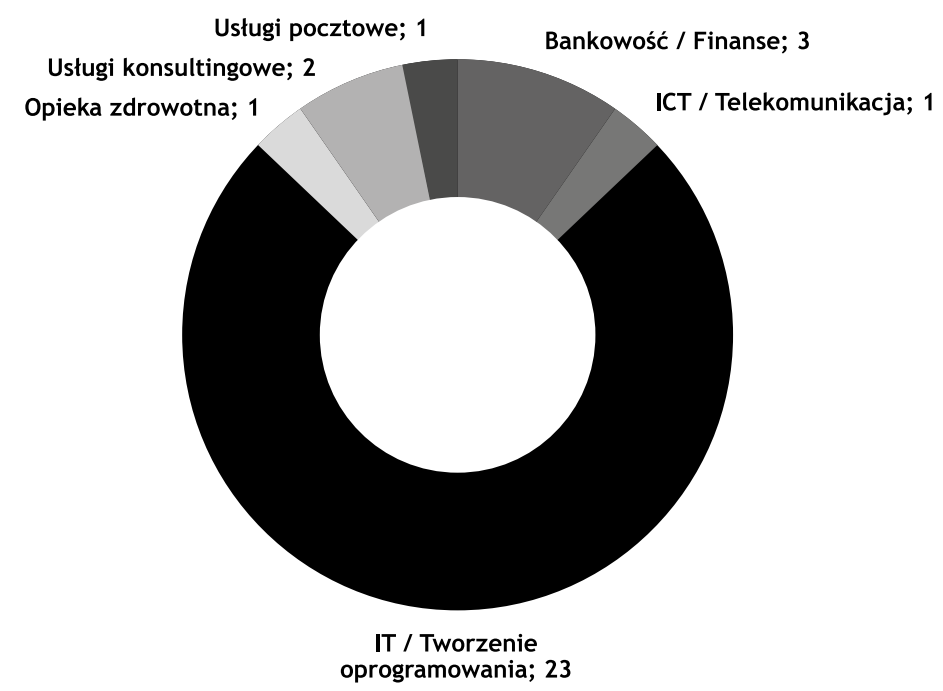

Rys. 1. Sektor respondentów oceniających badane zespoły projektowe Źródto: opracowanie własne 


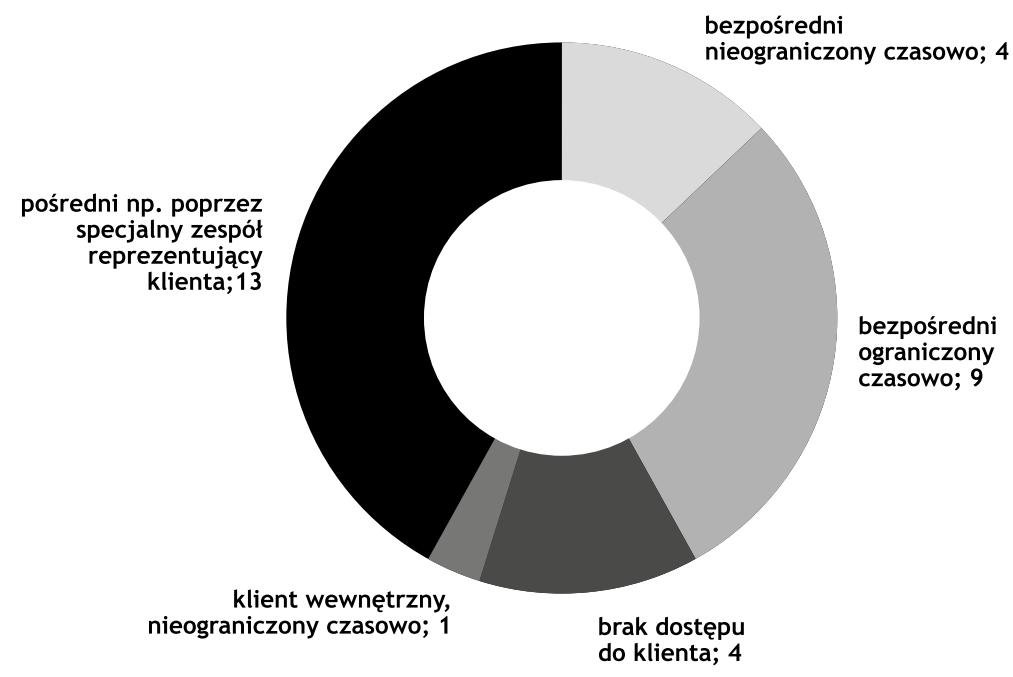

Rys. 2. Rodzaj dostępu do klienta badanego zespołu projektowego Źródto: opracowanie wtasne

dane zostały zagregowane do poziomu grupy w celu sprawdzenia, które grupy praktyk, a tym samym - które elementy podejścia zwinnego reprezentowane przez wybrane praktyki są najczęściej stosowane przez zespoły w ich codziennej pracy. Należy podkreślić, że wartość współczynnika Alfa Cronbacha, wskazująca na akceptowalny naukowo poziom dokładności pomiarowej daną skalą, w przypadku większości badanych grup praktyk, wynosiła powyżej 0,75. Jedynym wyjątkiem były praktyki związane z multidyscyplinarnością zespołu, co oznacza, że w dalszych badaniach grupa ta wymaga korekty pozycji testowych oraz sprawdzenia poprawności pomiaru na większej próbie. Być może oznacza to również, że praktyki związane $\mathrm{z}$ multidyscyplinarnością zespołu są często trudne do oceny i realizacji, stąd w wynikach mogą się pojawiać dwuznaczne rezultaty.

W tabeli 2 zaprezentowano podstawowe statystyki opisowe charakteryzujące zakres wykorzystania wybranych grup praktyk zwinnych.

Na podstawie statystyk opisowych grup praktyk zwinnych pochodzących z wyników badań ankietowych (tab. 2) można stwierdzić, że:

- Grupa praktyk związanych z dostarczaniem działającego produktu (w rozumieniu stosowania przyrostowości, iteracyjności oraz stałego tempa prac) jest najczęściej stosowana przez badane zespoły projektowe. Może to świadczyć o największym znaczeniu tych praktyk w codziennej pracy zespołu w realizacji jego zadań. Drugą w kolejności najczęściej stosowaną grupą praktyk była codzienna współpraca i bezpośrednia komunikacja, która również stanowi podstawę działania podejścia zwinnego.

- Grupa praktyk związanych z ciągłym doskonaleniem stosowana była najrzadziej z wszystkich - jak pokazano, średnia częstotliwość stosowania praktyk ciągłej poprawy i rozwoju przez zespoły była najmniejsza. Może to jednak wskazywać na znacznie większy stopień trudności w implementacji tych praktyk przez badane zespoły projektowe niż na ich mniejszy priorytet.

- Większa skośność w wynikach związanych z dostarczaniem działającego produktu może z kolei potwierdzać wcześniejsze wnioski o znacznie większym znaczeniu tych praktyk w codziennej organizacji pracy zespołu, a wręcz konieczność ich implementacji. Znacznie więcej wysokich ocen potwierdza, że praktyki te są stosowane bardzo często lub praktycznie zawsze, ponieważ bez nich podejście zwinne nie może funkcjonować.

- W przypadku pozostałych grup praktyk (poza grupami DWP oraz DCC) pomiary zakresu ich stosowania mają rozkłady przypominające bardziej rozkłady symetryczne niż inne rozkłady skośne. Powinno to jednak zostać potwierdzone i porównane na większej próbie. W tym miejscu należy wskazać, że normalność rozkładów pomiaru grup praktyk jest ważnym założeniem z perspektywy badań statystycznych, gdyż założenie takie pozwala wykorzystać średnią oraz odchylenie standardowe $z$ tabeli 2 do oceny i porównania częstości stosowania grup praktyk zwinnych w badanych zespołach. W tym badaniu, przy 31-elementowej próbie, może to stanowić o błędzie pomiaru.

W kolejnym etapie prowadzonych badań ilościowych przeanalizowano korelacje pomiędzy zakresem (częstotliwością) stosowania określonych praktyk zwinnych a charakterystykami zespołów lub ich środowisk. W tym celu wyznaczono współczynniki korelacji rang rho Spearmana. Wyniki zestawiono w tabeli 3.

Na podstawie analizy wyników tej części badań i istotnych statystycznie korelacji (zaznaczonych pogrubioną czcionką w tab. 3) można sformułować następujące wnioski:

- Grupa praktyk dotyczących codziennej współpracy i bezpośredniej komunikacji jest istotnie skorelowana z sektorem działalności, w którym pracuje dany zespół. Jak pokazano powyżej, w większości badanych przypadków (rys. 1) są to zespoły wytwarzające oprogramowanie, w których codzienna współpraca i komunikacja jest elementem niezbędnym do realizacji ich zadań projektowych ze względu na bardzo dużą ilość wymienianych informacji oraz potrzeb związanych z dzieleniem się wiedzą.

- Grupa praktyk związanych z pomiarem działającego produktu i satysfakcją klienta jest skorelowana istotnie z rozmiarem zespołu. W tym przypadku można potwierdzić przekonania, że standardowy i rekomendo- 
Tabela 1. Badane praktyki zwinne (w podziale na zidentyfikowane grupy)

DWP - DOSTARCZANIE DZIALAJACCEGO PRODUKTU (przyrostowość, iteracyjność, stałe tempo)

DWP1 - Praca w krótkich iteracjach.

DWP2 - Dostarczanie oprogramowania w iteracjach o stałej długości.

DWP3 - Dostarczanie oprogramowania w iteracjach bezpośrednio następujących po sobie.

DWP4 - Dostarczanie w każdej iteracji nowego fragmentu funkcjonalności działającego oprogramowania.

TEP - MISTRZOSTWO TECHNICZNE \& WŁASNOŚĆ PRODUKTU (prostota, otwartość na zmiany)

TEP1 - Stosowanie standardów kodowania w tworzonym oprogramowaniu.

TEP2 - Stosowanie refaktoryzacji kodu w tworzonym oprogramowaniu.

TEP3 - Uwzględnianie zmian wymagań klienta w tworzonym oprogramowania.

TEP4 - Wprowadzanie zmian w dowolnej części istniejącego oprogramowania.

\section{WPM - POMIAR DZIALAJĄCEGO PRODUKTU (satysfakcja klienta)}

WPM1 - Realizowanie zadań zgodnie z ich priorytetem w kolejce.
WPM2 - Prezentowanie tworzonego oprogramowania klientowi lub jego reprezentantom.
WPM3 - Stosowanie praktyk ciągłego testowania i wdrażania tworzonego oprogramowania.
WPM4 - Stosowanie kryteriów realizacji i akceptacji ukończonych zadań projektowych.

DCC - CODZIENNA WSPÓŁPRACA \& KOMUNIKACJA

DCC1 - Stosowanie bezpośrednich form komunikacji.

DCC2 - Prowadzenie spotkań synchronizacyjnych w celu wzajemnej komunikacji.

DCC3 - Wykorzystywanie historyjek użytkownika.

DCC4 - Stosowanie praktyk dzielenia się wiedzą.

AUT - AUTONOMIA (samoorganizacja)

AUT1 - Praca nad wymaganiami do tworzonego oprogramowania.

AUT2 - Planowanie pracy w danej iteracji.

AUT3 - Organizowanie swojej pracy w danej iteracji.

AUT4 - Decydowanie o sposobie tworzenia oprogramowania.

MDT - MULTIDYSCYPLINARNY ZESPÓŁ (zróżnicowanie umiejętności)

MDT1 - Zespół składa się z członków o różnych kompetencjach w tworzeniu oprogramowania.

MDT2 - Zespół składa się z członków potrafiących pełnić różne role.

MDT3 - Zespół składa się z członków o różnym doświadczeniu w tworzeniu oprogramowania.

MDT4 - Zespół składa się z członków o wyjątkowo wysokich kwalifikacjach, tzw. gwiazd kompetencyjnych.

\section{CIM - CIĄGLE DOSKONALENIE}

CIM1 - Wykonywanie przeglądów stosowanych procesów i praktyk.

CIM2 - Usprawnianie procesów tworzenia oprogramowania.

CIM3 - Automatyzowanie powtarzalnych zadań.

CIM4 - Podnoszenie własnych kompetencji.

Objaśnienia: DWP - Delivery of Working Product/Dostarczanie Działającego Produktu

TEP - Technical Excellence and Product Ownership/Mistrzostwo Techniczne \& Własność Produktu

WPM - Working Product Measurement/Pomiar Działającego Produktu

DCC - Daily Collaboration \& Communication/Codzienna Współpraca \& Komunikacja

AUT - Autonomy/Autonomia

MDT - Multidisciplinary Team/Multidyscyplinarny Zespót

CIM - Continuous Improvement/Ciaggte Doskonalenie

Źródło: opracowanie własne

wany rozmiar zespołu w podejściu zwinnym powinien wynosić 3-9 osób.

- W przypadku grupy praktyk związanych z autonomią i samoorganizacją istnieje istotna statystycznie korelacja $\mathrm{z}$ rodzajem dostępu zespołu do klienta. Wydaje się to potwierdzać, że zespół będzie w stanie pracować tym bardziej samodzielnie i niezależnie, im lepszy posiada dostęp do klienta - to znaczy taki, który umożliwia mu otrzymywanie częstej informacji zwrotnej dotyczącej dostarczanego produktu.

\section{Równorzędność i determinanty doboru praktyk zwinnych - wyniki badań jakościowych}

N trakcie prowadzonych wywiadów, które towarzyszyły dyskusjom nad poprawnością konstrukcji narzędzia badawczego (kwestionariusza ankiety), respondenci bardzo chętnie odnosili się do problemów doboru i znaczenia praktyk zwinnych. Wywiady (ponad godzinne) z każdym $z$ trenerów zostały poddane transkrypcji, a następnie 
Tabela 2. Statystyki opisowe grup praktyk zwinnych

\begin{tabular}{|c|c|c|c|c|c|c|c|}
\hline & DWP & TEP & WPM & DCC & AUT & MDT & $\mathrm{CIM}$ \\
\hline Średnia & 4,34 & 3,60 & 3,69 & 4,10 & 3,88 & 3,82 & 3,52 \\
\hline Mediana & 4,50 & 3,75 & 3,75 & 4,25 & 4,00 & 4,00 & 3,50 \\
\hline Dominanta & 5,00 & 3,75 & 3,75 & 4,00 & 3,75 & 3,50 & 3,25 \\
\hline Odchylenie standardowe & 0,75 & 0,82 & 0,97 & 0,73 & 0,87 & 0,65 & 0,88 \\
\hline Skośność & $-1,57$ & $-0,94$ & $-0,80$ & $-1,81$ & $-1,00$ & $-0,60$ & $-0,57$ \\
\hline
\end{tabular}

Źródło: opracowanie własne

Tabela 3. Korelacja pomiarów grup praktyk zwinnych z charakterystyką zespołu

\begin{tabular}{|c|c|c|c|c|c|c|}
\hline & & $\begin{array}{c}\text { Sektor } \\
\text { działalności }\end{array}$ & $\begin{array}{l}\text { Ilość osób } \\
\text { w zespole }\end{array}$ & $\begin{array}{l}\text { Złożoność } \\
\text { realizowanych } \\
\text { projektów }\end{array}$ & $\begin{array}{c}\text { Doświadczenie } \\
\text { w podejściu } \\
\text { zwinnym }\end{array}$ & $\begin{array}{l}\text { Rodzaj dostępu } \\
\text { do klienta }\end{array}$ \\
\hline \multirow{7}{*}{$\begin{array}{l}\text { Współczynnik } \\
\text { korelacji rho } \\
\text { Spearmana }\end{array}$} & DWP &,- 114 &,- 307 &,- 242 &,- 017 &,- 107 \\
\hline & TEP &,- 083 &,- 311 & ,031 &,- 067 &,- 322 \\
\hline & WPM &,- 049 & $-0,542$ &,- 101 & , 169 &,- 243 \\
\hline & DCC & $-0,396$ &,- 099 & 095 & ,049 & ,036 \\
\hline & AUT &,- 042 &,- 194 &,- 078 &,- 063 & $-0,36$ \\
\hline & MDT &,- 104 &,- 118 & ,008 & 011 &,- 265 \\
\hline & CIM &,- 283 &,- 209 & ,231 &,- 012 &,- 103 \\
\hline
\end{tabular}

Źródło: opracowanie własne

przeanalizowano je, koncentrując uwagę na problemach doboru, przede wszystkim priorytetyzacji i uwarunkowań efektywności wskazanych praktyk zwinnych.

Analiza przekonań wyrażanych przez respondentów $\mathrm{w}$ przeprowadzonych wywiadach pozwala stwierdzić, że dwanaście zasad Manifestu Agile stanowi najlepsze źródło do wyboru fundamentalnego zbioru praktyk zwinnych w przypadku każdego zespołu projektowego: „(...) ja bym włączył dokładnie te praktyki z 12 zasad Manifestu Agile” (Respondent 1). Dyskusja z ekspertami na temat trafności doboru praktyk oraz ich grupowania zastosowana w prezentowanym badaniu również wskazywała na poprawność wyboru i klasyfikacji.

Analizując wyniki badań jakościowych (wywiadów), można dostrzec interesujące, chociaż sprzeczne, opinie dotyczące znaczenia i równorzędności wybranych grup praktyk zwinnych. Pytania dotyczące tego, czy praktyki zwinne powinno się intencjonalnie priorytetyzować, czy istnieją grupy praktyk o szczególnym znaczeniu i grupy praktyk, z których zespół może zrezygnować bez strat dla wyników swojej pracy, okazywały się budzić albo wyraźne zaciekawienie, albo raczej zniecierpliwienie. $\mathrm{W}$ dyskusjach $\mathrm{z}$ respondentami pojawiło się wiele zdecydowanych stwierdzeń, że praktyk zwinnych nie powinno się analizować z perspektywy pozycji, preferencji czy rangowania - podobnie jak nie ma priorytetyzacji w wartościach czy zasadach Manifestu Agile.

Zdaniem innych badanych, intencjonalne przyznawanie pierwszeństwa różnym praktykom może być uwarunkowane oceną i percepcją danego zespołu projektowego. Dany zespół zwinny decyduje o wykorzystywanych przez siebie praktykach: „priorytetyzacja praktyk ma miejsce w kontekście konkretnego zespotu (...) praktyki to sa tylko pewne reguly gry i będą najczęściej bardzo różnie wybierane przez różne zespoły" (Respondent 2). Podobną argumentacją za brakiem prioryte- tyzacji praktyk i ich intencjonalnego wyboru dokonywanego przez zespoły była opinia respondenta, że „szeregowanie nie wnosi tu wartości (...) nie ma to sensu, szczególnie, że to bardzo zależy od kontekstu zespołu" (Respondent 12).

Należy podkreślić, że pojawiły się jednak również przeciwne opinie. Zdaniem dużej części respondentów (5 na 16 badanych) to grupa praktyk dotycząca ciągłej poprawy i rozwoju wydaje się tą najważniejszą: „nie da się całego tego procesu zaprojektować czy zaprogramować na sukces od pierwszej chwili jego zastosowania i trzeba iteracyjnie dochodzić do tego, co jest właściwe, a co być może nie, tzn. które praktyki będa właściwe $w$ kontekście danego zespołu czy produktu, a które nie" (Respondent 1). Zastosowanie podejścia zwinnego w zespole stanowi pewnego rodzaju wyzwanie i wymaga czasu na procesy adaptacji, zależnie od charakterystyki, doświadczenia oraz środowiska, w jakim pracuje dany zespół projektowy.

W dyskusjach nad uniwersalnością i uwarunkowaniami stosowania praktyk, respondenci odnosili się także do problemu braku aplikacji wybranych praktyk. Występowanie lub brak określonej praktyki jako determinanta sprawnej realizacji projektów była ilustrowana na przykład problemem multidyscyplinarności zespołu. W tym kontekście wartą przytoczenia jest opinia respondenta, mówiąca, że: „(...) multidyscyplinarność to jest coś, do czego się raczej dąży, ale nie zawsze $z$ tym startujemy, czasami $z$ zespołu odchodzi ekspert i zespół zwinny nadal sobie radzi (...)" (Respondent 15). Respondent potwierdza, że w codziennej praktyce zarządzania zespołami, mimo braku multidyscyplinarności, stosowane podejście zwinne dostarcza wymiernych korzyści.

Jak wskazywali respondenci, dostarczanie korzyści z zastosowania praktyk zwinnych nie jest „za darmo” i najczęściej wymaga znacznych inwestycji oraz zmian na poziomie nie tylko zespołu projektowego, ale również środowiska jego 
pracy, w tym całej organizacji: „Zwinność wymaga zmian systemu operacyjnego (zmian $w$ organizacji), zmiany głowy, mentalności, kultury organizacyjnej. Drugie ograniczenie jest takie, że wchodzq $w$ to duże organizacje $i$ skalowalność jest tu problemem." (Respondent 6). Wnioski te wymagają jednak szerszych badań praktyki zarządzania zespołami stosującymi metodyki zwinne, stanowią jednak ciekawą lukę i inspirację do przyszłych badań naukowych.

\section{Podsumowanie}

$\mathbf{R}$ ozwój zwinnego zarządzania projektami i coraz powszechniejsze stosowanie podejścia zwinnego w realizacji projektów, nie tylko informatycznych, powoduje potrzebę dalszych badań nad praktykami zwinnymi. Zwinne zespoły projektowe, jak pokazują wyniki badania, mają do dyspozycji wachlarz praktyk dotyczących dostarczania działającego produktu, mistrzostwa technicznego i własności produktu, pomiaru działającego produktu, codziennej współpracy i komunikacji, autonomii, multidyscyplinarności zespołu czy ciągłego doskonalenia. Ich wybór, skuteczność i osiągane korzyści zależą zarówno od samego zespołu, jak i od kontekstu jego funkcjonowania.

Jak wynika $\mathrm{z}$ badań zaprezentowanych $\mathrm{w}$ tym artykule, szczególne znaczenie mają praktyki bezpośrednio powiązane z Manifestem Agile, zwłaszcza praktyki związane z dostarczaniem działającego produktu oraz codzienną współpracą i komunikacją, ale ich równorzędność może budzić dyskusje i kontrowersje. Podobnie dyskusyjny jest ich uniwersalizm: to zespół zwinny dobiera praktyki zależnie od preferowanego sposobu pracy i kompetencji. Co więcej, potrzeba ciągłego doskonalenia i rozwoju jest niewątpliwie bardzo istotna w zarządzaniu projektami, co podkreślano w wywiadach, jednak - jak pokazały wyniki badań - implementacja tych praktyk może stanowić wyzwanie i napotykać trudności.

Podstawowym ograniczeniem badań prezentowanych w tym artykule jest ich reprezentatywność. Uogólnianie wyników na populację nie jest uprawnione, uzyskane wyniki wskazują jednak na potrzebę kontynuacji badań, a brak jednoznacznych rozstrzygnięć, różnic zdań i kontrowersji może być inspiracją do kolejnych pytań badawczych. Nie budzi bowiem wątpliwości to, że rozwój praktyk zwinnego zarządzania oraz badań naukowych wyjaśniających ich sens i uwarunkowania jest wyzwaniem dla wszystkich zainteresowanych nowoczesnym zarządzaniem projektami.

\section{dr hab. inż. Alina Kozarkiewicz, prof. AGH AGH Akademia Górniczo-Hutnicza Wydział Zarządzania \\ ORCID: 0000-0002-0683-3148 e-mail: akozarki@zarz.agh.edu.pl}

\author{
mgr inż. Paweł Paterek \\ AGH Akademia Górniczo-Hutnicza \\ Wydział Zarządzania \\ ORCID: 0000-0002-1482-6837 \\ e-mail: pawel.paterek@gmail.com
}

\section{Przypisy}

1),Praktyka zarządzania” jest tu rozumiana jako rodzaj działania związanego z zarządzaniem, które przyczynia się do realizacji procesu i może wykorzystywać jedno lub więcej narzędzi lub technik - wg standardu PMI z 2008 r., s. 433.

2) https://www.linkedin.com.

3) Jako zespół projektowy rozumiemy tu pojedynczy zespół pracujący nad produktem w ramach określonego projektu. Zespół ten może współpracować z innymi zespołami realizującymi zadania $\mathrm{z}$ tego samego projektu.

4) W ramach badań statystycznych sprawdzono istotność statystyczną różnic między wystąpieniami danych wartości w zmiennych metryczkowych. Analiza ta weryfikuje hipotezę o losowej zmienności wystąpień, czyli o względnie równych proporcjach odpowiedzi na wszystkie odpowiedzi danej zmiennej (brak istotnej zależności statystycznej).

\section{Bibliografia}

[1] Agile Alliance (2019), Agile Alliance, https://www.agilealliance. org/, data dostępu: 12.01.2019 r.

[2] Beck K., Beedle M., van Bennekum A., Cockburn A., Cunningham W., Fowler M., Grenning J., Highsmith J., Hunt A., Jeffries J., Kern J., Marick B., Martin R.C., Mellor S., Schwaber K., Sutherland J., Thomas D. (2001), Manifesto for Agile Software Development, http://agilemanifesto.org, access date: 12.01.2019.

[3] Boehm B., Turner R. (2005), Management Challenges to Implementing Agile Processes in Traditional Development Organizations, „IEEE Software”, Vol. 22, No. 5, pp. 30-39.

[4] Bojar E., Bojar M., Bojar W. (2018), Prawne aspekty podejmowania decyzji menedżerskich, Wyd. Politechnika Lubelska, Lublin.

[5] Cabała P. (red.), (2016), Metody doskonalenia procesów zarzadzania projektami w organizacji, Difin, Warszawa.

[6] Conforto E.C., Salum F., Amaral D.C., da Silva S.L., de Almeida L.F.M. (2014), Can Agile Project Management Be Adopted by Industries Other than Software Development? „Project Management Journal", Vol. 45, No. 3, pp. 21-34.

[7] Henriksen A., Pedersen S.A.R. (2017), A Qualitative Case Study on Agile Practices and Project Success in Agile Software Projects, „Journal of Modern Project Management”, Vol. 5, No. 1, pp. 63-73.

[8] Highsmith J. (2004), Agile Project Management: Creating Innovative Products, Addison-Wesley, US, Boston.

[9] Jalali S., Wohlin C. (2011), Global Software Engineering and Agile Practices: A Systematic Review, „Journal of Software: Evolution and Process", Vol. 24, No. 6, pp. 643-659.

[10] Karvonen T., Behutiye W., Oivo M., Kuvaja P. (2017), Systematic Literature Review on the Impacts of Agile Release Engineering Practices, „Information and Software Technology”, Vol. 86, No. 6, pp. 87-100.

[11] Kozarkiewicz A., Paterek P. (2016), Zmiana metodyki zarzadzania projektami a transformacja przedsiębiorstwa - uwarunkowania, proces i efekty, Studia Ekonomiczne. Zeszyty Naukowe Uniwersytetu Ekonomicznego w Katowicach, Nr 299/16, s. $187-196$.

[12] Nerur S., Mahapatra R., Mangalaraj G. (2005), Challenges of Migrating to Agile Methodologies, "Communication of the ACM", Vol. 48, No. 5, pp. 72-78. 
[13] Nowak S. (2012), Metodologia badań społecznych, Wyd. Naukowe PWN, Warszawa.

[14] Panasiewicz L., Paterek P. (2017), Metodyki zwinne w praktyce organizacyjnego uczenia się, „Ekonomika i Organizacja Przedsiębiorstwa", Nr 12(814), s. 32-43.

[15] Recker J., Holten R., Hummel M., Rosenkranz C. (2017), How Agile Practices Impact Customer Responsiveness and Development Success: A Field Study, „Project Management Journal”, Vol. 48, No. 2, pp. 99-121.

[16] Schwaber K. (2004), Agile Project Management with Scrum, Microsoft Press, US, Redmond.

[17] Sheffield J., Lemétayer J. (2013), Factors Associated with the Software Development Agility of Successful Projects, ,International Journal of Project Management", Vol. 31, No. 3, pp. 459-472.

[18] Singh A., Singh K., Sharma N. (2014), Agile Knowledge Management: A Survey of Indian Perceptions, „Innovations in Systems and Software Engineering", Vol. 10, No. 4, pp. 297-315.

[19] Spałek S. (2013), Dzielenie się wiedza projektowa w polskich przedsiębiorstwach. Zarys problematyki, „Zarządzanie i Finanse/Journal of Management and Finance", Vol. 11, No. 1, Part 2, pp. 305-315.

[20] Stettina C.J., Hörz J. (2015), Agile Portfolio Management: An Empirical Perspective on the Practice in Use, „International Journal of Project Management", Vol. 33, No. 1, pp. 140-152.

[21] Trocki M. (red.), (2013), Nowoczesne zarzadzanie projektami, Polskie Wydawnictwa Ekonomiczne, Warszawa.

[22] Vázquez-Bustelo D., Avella L., Fernández E. (2007), Agility Drivers, Enablers and Outcomes: Empirical Test of an Integrated Agile Manufacturing Model, „International Journal of Operations i Production Management", Vol. 27, No. 12, pp. 1303-1332.

[23] Wirkus M., Zejer P. (2017), Uwarunkowania zastosowania metodyk zwinnych w przedsiębiorstwie, Zeszyty Naukowe Politechniki Śląskiej, Seria: Organizacja i Zarządzanie, Nr 114, s. 561-576.
[24] Wyrozębski P. (2014), Zarządzanie wiedza projektową, Difin, Warszawa.

[25] Wysocki R.K. (2014), Effective Project Management: Traditional, Agile, Extreme, John Wiley \& Sons Inc., US, Indianapolis, Indiana.

\section{Agile Practices in Project Teams - Results of Empirical Research}

\section{Summary}

Software development teams use various agile practices to organize their work. The aim of this paper is to identify and systematize the key agile practices in the management of project teams, as well as to determine their priorities. In the paper, the scope of agile practices - analysed in terms of the frequency of their application - as well as the factors affecting the selection of practices are being investigated. The results of empirical research in the form of survey and experts' interviews demonstrate the variety of agile practices used and confirm the influence of project team peculiarity and context on the adoption of practices. The most important practices are these related to Agile Manifesto, however, according to this research, it is not easy to prioritize them, as agile teams select practices on the basis of their particular way of working and unique set of their competences. The research demonstrates the significance of continuous improvement and team development, which, in fact, requires efforts and investments.

\section{Keywords}

agile practices, project management, project team 